\title{
Chemical characterization of soluble polysaccharides in the red alga Acanthophora spicifera from La Paz Bay, Baja California Sur, Mexico
}

\section{Caracterización química de los polisacáridos solubles del alga roja Acanthophora spicifera de la bahía de La Paz, Baja California Sur, México}

\author{
Valérie Chantal Gabrielle Schnoller ${ }^{1}$, Gustavo Hernández-Carmona ${ }^{1}$, Enrique Hernández-Garibay ${ }^{2 *}$, \\ Juan Manuel López-Vivas ${ }^{3}$, Mauricio Muñoz-Ochoa ${ }^{1}$ \\ ${ }^{1}$ Laboratorio de Química de Algas Marinas, Centro Interdisciplinario de Ciencias Marinas (CICIMAR), \\ Instituto Politécnico Nacional (IPN), Av. Instituto Politécnico Nacional, s/n, Playa Palo de Santa Rita, \\ CP 23096, La Paz, Baja California Sur, Mexico. \\ 2 Centro Regional de Investigaciones Acuícolas y Pesqueras de Ensenada (CRIAP), Instituto Nacional de Pesca \\ y Acuacultura, Carretera Tijuana-Ensenada, km 97.5, CP 22760, Ensenada, Baja California, Mexico. \\ 3 Departamento Académico de Ciencias Marinas y Costera, Universidad Autónoma de Baja California Sur, \\ Carretera al Sur, km 5.5, Col. Mezquitito, CP 23080, La Paz, Baja California Sur, Mexico.
}

* Corresponding author. E-mail: enrique.garibay@inapesca.gob.mx

\begin{abstract}
Acanthophora spicifera is an invasive red alga that was recently detected in La Paz Bay, Baja California Sur, Mexico, where it has developed into a large biomass. Because it is a new species in the region, the characteristics and properties of the soluble polysaccharides (SPs) that it contains are unknown. To determine the content, chemical composition, and properties of SPs in A. spicifera, monthly samplings were carried out in 2013 at Point Roca Caimancito in La Paz Bay, and native and alkali-treated polysaccharides were extracted and characterized. The alkaline treatment produced lower yields and modified the composition of A. spicifera SPs. The polysaccharides obtained before or after the alkaline treatment had low viscosity and did not have gelling properties. In line with the obtained results, the molar ratio of components (galactose, 3,6-anhydrogalactose, sulfates [Gal:3,6-AG:sulfates]) for native (1.00:0.30:0.23) and alkali-treated (1.00:0.30:0.17) polysaccharides showed that $A$. spicifera SPs have a lower proportion of sulfates than that in polysaccharides belonging to carrageenans but greater than that in polysaccharides belonging to true agar. The Fourier-transform infrared spectra of SPs showed characteristic signals for sulfated galactans, with the presence of pyruvic acid; after the alkaline treatment, characteristic signals for agar-type polysaccharides (agaroid) were observed. Although A. spicifera polysaccharides have no gelling properties, additional studies are needed to clarify the structure of the SPs it contains to find appropriate uses for this resource.
\end{abstract}

Key words: Acanthophora spicifera, agar, alkaline treatment, seasonal variation, soluble polysaccharides.

RESUMen. Acanthophora spicifera es un alga roja invasiva que recientemente fue detectada en la bahía de La Paz, Baja California Sur, México, donde se ha desarrollado en grandes biomasas. Debido a que es una nueva especie en la región, se desconocen las características y las propiedades de los polisacáridos solubles (PS) que contiene. Con el propósito de determinar el contenido, la composición química y las propiedades de los PS de A. spicifera, durante el año 2013, se realizaron muestreos mensuales en punta Roca Caimancito en la bahía de La Paz, y se extrajeron y caracterizaron los PS nativos y los PS con tratamiento alcalino. El tratamiento alcalino redujo el rendimiento y modificó la composición de los PS de A. spicifera. Los polisacáridos obtenidos antes o después del tratamiento alcalino fueron de baja viscosidad y no gelificaron. En concordancia con los resultados obtenidos, la razón molar de los componentes (galactosa, 3,6-anhidrogalactosa, sulfatos [Gal:3,6-AG:sulfatos]) para los polisacáridos nativos (1.00:0.30:0.23) y los polisacáridos con tratamiento alcalino (1.00:0.30:0.17) mostró que los PS de A. spicifera poseen una menor proporción de sulfatos que la que corresponde a los polisacáridos que pertenecen a los carragenanos, pero mayor que la que corresponde a los polisacáridos pertenecientes al agar verdadero. Los espectros obtenidos de la espectrometría infrarroja con transformada de Fourier de los PS mostraron señales características para galactanos sulfatados, con la presencia de ácido pirúvico; después del tratamiento alcalino, se observaron señales características para polisacáridos del tipo agar (agaroideo). Aunque los polisacáridos de A. spicifera no tienen propiedades gelificantes, es necesario realizar estudios adicionales para determinar la estructura de los PS que contiene esta especie con el propósito de encontrar usos apropiados para este recurso.

Palabras clave: Acanthophora spicifera, agar, tratamiento alcalino, variación estacional, polisacáridos solubles.

\section{INTRODUCTION}

The wide diversity of marine environments on the coasts of Mexico, from temperate oceans to tropical waters, favors the development of a wide diversity of marine algal species.

\section{INTRODUCCIÓN}

La amplia diversidad de ambientes marinos en las costas de México, desde las aguas templadas del océano hasta las tropicales, propicia el desarrollo de una amplia diversidad de 
Nearly 1,000 species of macroalgae can be found on these coasts (Robledo 1998). It is common for the floristic pattern of a locality to be affected by the accidental or deliberate introduction of new macroalgae species (invasive algae) (Pedroche and Sentíes 2003, Williams and Smith 2007). That is the case of the red alga Acanthophora spicifera (Børgesen 1910), a native species from the Caribbean and Florida coasts. It was recorded as an invasive species on the Central Pacific Islands (Russell 1992, Tsuda et al. 2008). Recently, A. spicifera, was found on the southwestern coasts of the Gulf of California, where it has formed extensive beds with considerable biomass (Fig. 1) (Riosmena-Rodríguez et al. 2009). On the other hand, marine algae are an important source of valuable soluble polysaccharides such as agar, carrageenan, and alginates (Painter 1983, Craigie 1990, Lobban and Harrison 1994). Generally, the composition and properties of the different polysaccharides in seaweeds are related to the physiological function in the corresponding taxonomic algal classification (Kloareg and Quatrano 1988, Miller 1997, Usov and Zelinsky 2013). Red algae, in particular, are known for producing polysaccharides belonging to the family of sulfated galactans. With a few possible exceptions, the structures of all the galactans in this group have a especies de algas marinas. En estas costas, es posible encontrar cerca de 1,000 especies de macroalgas (Robledo 1998). Sin embargo, es común que el patrón florístico de una localidad se vea afectado por la introducción accidental o deliberada de nuevas especies de macroalgas (algas invasoras) (Pedroche y Sentíes 2003, Williams y Smith 2007). Este es el caso del alga roja Acanthophora spicifera (Børgesen 1910), una especie nativa de las costas del Caribe y Florida. Fue registrada como una especie invasora en las islas del Pacífico central (Russell 1992, Tsuda et al. 2008). Recientemente, A. spicifera fue encontrada en las costas del suroeste del golfo de California, donde formó extensas praderas con considerable biomasa (Fig. 1) (Riosmena-Rodríguez et al. 2009). Por otra parte, las algas marinas son una fuente importante de polisacáridos solubles valiosos como agar, carragenano y alginatos (Painter 1983, Craigie 1990, Lobban y Harrison 1994). Generalmente, la composición y las propiedades de los diferentes polisacáridos de algas marinas están relacionadas con su función fisiológica en su correspondiente clasificación taxonómica (Kloareg y Quatrano 1988, Miller 1997, Usov y Zelinsky 2013). En particular, las algas rojas se caracterizan por producir polisacáridos pertenecientes a la familia de los galactanos sulfatados. Con algunas posibles

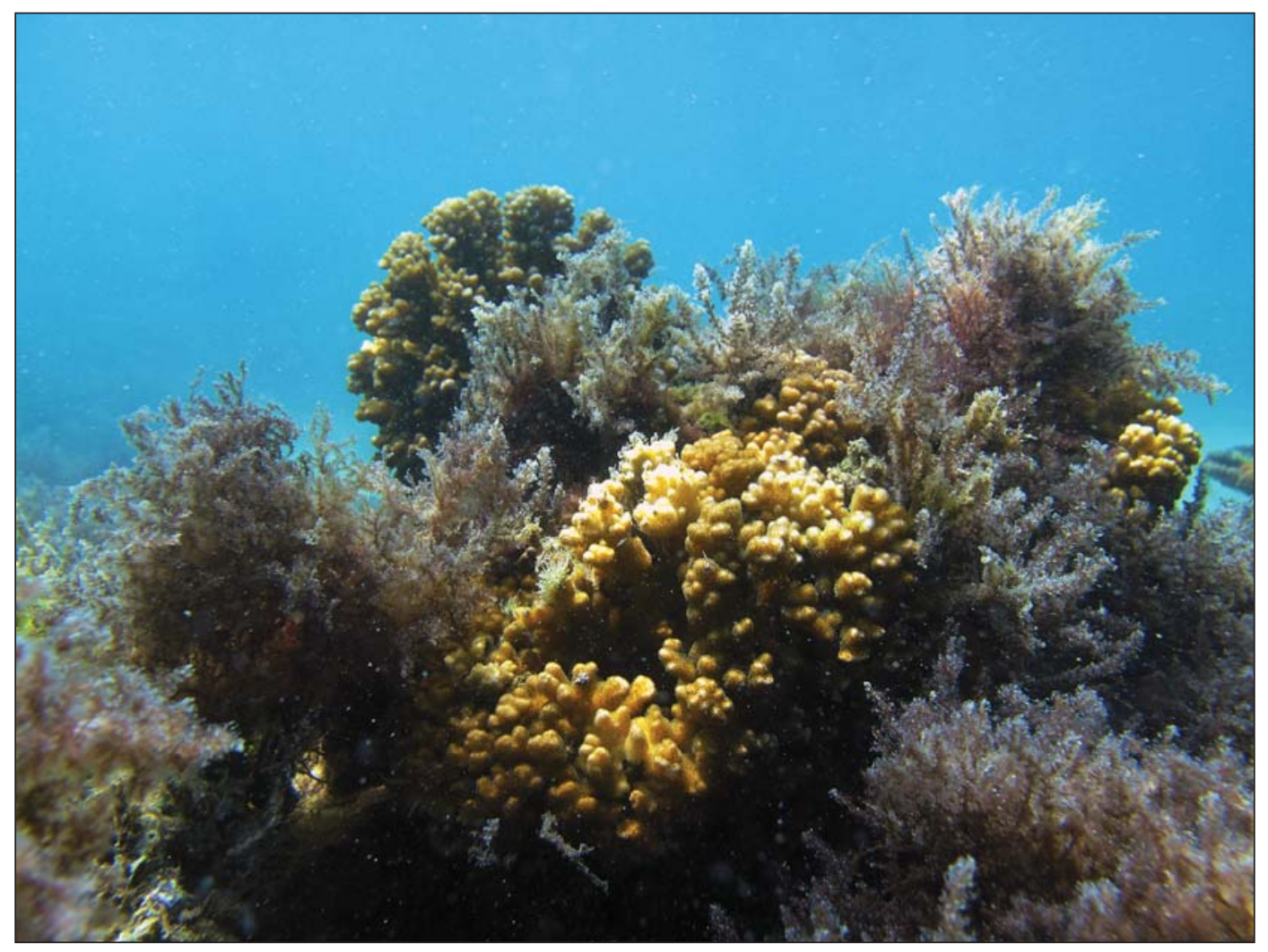

Figure 1. Acanthophora spicifera overgrowing on Pocillopora and Porites coral colonies off Point Roca el Caimancito, La Paz, Baja California Sur, Mexico.

Figura 1. Acanthophora spicifera creciendo sobre colonias de corales Pocillopora y Porites frente a punta Roca el Caimancito, La Paz, Baja California Sur, México. 
common, simplifying feature: they use as basis linear chains of $\beta$-D-galactopyranose residues glycosidically linked through positions 1 and 3 (A units) and $\alpha$-galactopyranose residues glycosidically linked through positions 1 and 4 (B units) in either the agar (levogyre [L] B unit) or the carrageenan (dextrogyre [D] B unit) (Painter 1983, Craigie 1990).

In the case of A. spicifera seaweed, which belongs to the order Ceramiales, previous studies have reported that it contains highly sulfated galactans, and studies using mainly Fourier-transform infrared (FTIR) spectroscopy suggest that it produces polysaccharides belonging to the carrageenan family, particularly the lambda type $(\lambda)$ (Table 1a) (Parekh et al. 1989, Cajipe 1990, Gomaa and Elshoubaky 2016). However, this is controversial as other more complete studies have shown that A. spicifera polysaccharides belong to the agaran family (Gonçalvez et al. 2002, Duarte et al. 2004, Seixas et al. 2007). Since A. spicifera is a new species in the La Paz Bay area, Baja California Sur, Mexico, no studies have been conducted on the characteristics of the polysaccharides it contains. The purpose of this research was to assess the seasonal content and chemical characteristics of the soluble polysaccharides in A. spicifera, native and alkali-treated, to determine the potential use for this species.

\section{MATERIALS AND METHODS}

\section{Collection of biological material}

Samples of A. spicifera were collected monthly from February to December 2013 off Point Roca El Caimancito $\left(24^{\circ} 12^{\prime} 12.91^{\prime \prime} \mathrm{N}, 110^{\circ} 18^{\prime} 3.43^{\prime \prime} \mathrm{W}\right)$, in La Paz Bay, Baja California Sur, Mexico. The samples were first sun-dried and milled to $\Phi \leq 2 \mathrm{~mm}$, then stored in plastic bags in a cool, dry place until analysis.

\section{Extraction of soluble polysaccharides}

\section{Native soluble polysaccharides}

Done in triplicate, $3 \mathrm{~g}$ of dried and milled seaweed samples were extracted by stirring at boiling point for $2 \mathrm{~h}$ in $90 \mathrm{~mL}$ of $0.1 \mathrm{M}$ phosphate buffer at $6.5 \mathrm{pH}$. Diatomaceuous earth was added as a filter aid and was vacuum filtered. To increase the ionic strength in the solution, sodium chloride $(\mathrm{NaCl})$ crystals were added up to $0.1 \mathrm{M}$, and soluble polysaccharides were precipitated by changing the solvent with 2 volumes of $96 \%$ ethanol. To remove the salts and water, the coagulum was first rinsed twice with $70 \%$ ethanol, then once with $96 \%$ ethanol, and then it was dried for $24 \mathrm{~h}$ at $60^{\circ} \mathrm{C}$ and weighed (Craigie and Leigh 1978).

\section{Alkali-treated soluble polysaccharides}

Done in triplicate, $3 \mathrm{~g}$ of dried and milled seaweed were treated with a solution of $6 \%$ potassium hydroxide $(\mathrm{KOH})$ excepciones, las estructuras de todos los galactanos en este grupo tienen una característica común y simplificadora: se basan en cadenas lineales de residuos de $\beta$-D-galactopiranosa unidas por enlaces glicosídicos a través de las posiciones 1 y 3 (unidades A) y los residuos de la $\alpha$-galactopiranosa unidos glicosídicamente a través de las posiciones 1 y 4 (unidades B) en el agar (levógira [L] la unidad B) y en el carragenano (dextrógira [D] la unidad B) (Painter 1983, Craigie 1990).

En el caso del alga $A$. spicifera, que pertenece al orden Ceramiales, estudios previos han reportado que produce galactanos altamente sulfatados, y los estudios que utilizaron principalmente espectrometría infrarroja con transformada de Fourier (FTIR, por sus siglas en inglés) sugieren que produce polisacáridos pertenecientes a la familia de los carragenanos, particularmente los del tipo lambda $(\lambda)$ (Tabla 1a) (Parekh et al. 1989, Cajipe 1990, Gomaa y Elshoubaky 2016). Sin embargo, esto es controversial ya que estudios más completos han demostrado que los polisacáridos de $A$. spicifera pertenecen a la familia de agaranos (Gonçalvez et al. 2002, Duarte et al. 2004, Seixas et al. 2007). Dado que A. spicifera es una especie nueva en la región de la bahía de la Paz, Baja California Sur, México, no se han realizado estudios sobre las características de los polisacáridos que contiene. Para determinar el posible uso de esta especie, el propósito de esta investigación fue evaluar el contenido estacional y las características químicas de los polisacáridos solubles que contiene $A$. spicifera, nativos y con tratamiento alcalino.

\section{MATERIALES Y MÉTODOS}

\section{Recolecta del material biológico}

Se realizaron muestreos mensuales de A. spicifera de febrero a diciembre de 2013 en punta Roca El Caimancito $\left(24^{\circ} 12^{\prime} 12.91^{\prime \prime} \mathrm{N} 110^{\circ} 18^{\prime} 3.43^{\prime \prime} \mathrm{W}\right)$, en la bahía de La Paz, Baja California Sur, México. Las muestras primero se secaron al sol y se molieron a un tamaño de partícula $\Phi \leq 2 \mathrm{~mm}$; luego se almacenaron en bolsas de plástico, en un lugar fresco y seco hasta que se analizaron.

\section{Extracción de los polisacáridos solubles}

\section{Polisacáridos solubles nativos}

Muestras de $3 \mathrm{~g}$ de algas secas (por triplicado) se extrajeron mediante la agitación constante a punto de ebullición en $90 \mathrm{~mL}$ de solución amortiguadora de fosfato al $0.1 \mathrm{M}, \mathrm{pH}$ de 6.5, durante $2 \mathrm{~h}$. Posteriormente, se añadió tierra de diatomeas como filtro-ayuda y se filtró al vacío. Para aumentar la fuerza iónica de la solución, se añadieron cristales de cloruro de sodio $(\mathrm{NaCl})$ hasta $0.1 \mathrm{M}$ y los polisacáridos solubles se precipitaron mediante un cambio de solvente con 2 volúmenes de etanol al 96\%. Para eliminar las sales y el agua, el coágulo se lavó primero 2 veces con etanol al $70 \%$ y luego 
Table 1. Disaccharide repeating units of lambda $(\lambda)$-carrageenan (a), native agaran (b), and ideal agarose (c).

Tabla 1. Unidades disacáridas repetitivas de lambda $(\lambda)$-carragenano (a), agar nativo (b) y agarosa idealizada (c).

\begin{tabular}{lll}
\hline Name \\
\hline -Carrageenan & $\begin{array}{c}\text { Repetitive idealized disaccharide } \\
\text { structure } \\
(\mathrm{A}-\mathrm{B})\end{array}$ & Full IUPAC* name \\
3-linked $\beta$-D-galactopyranose 2-sulfate \\
(A) and 4-linked $\alpha$-D-galactopyranose \\
2,6-disulfate (B)
\end{tabular}

(b) Repetitive dimer in the agaran family (native)

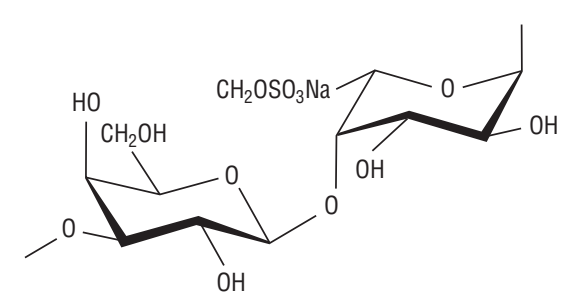

(c)

Repetitive dimer of agarose in the agaran family (alkali-treated)

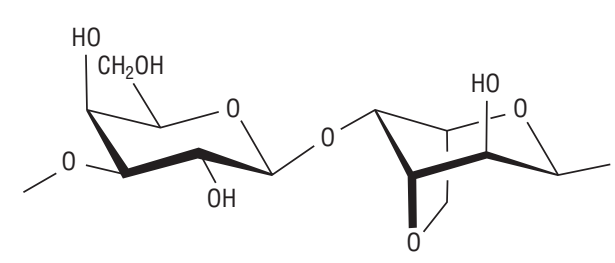

3-linked $\beta$-D-galactopyranose (A) and 4-linked $\alpha$-L-galactopyranose 6-sulfate (B)

3 linked $\beta$-D-galactopyranose (A) and 4-linked $\alpha$-L-3,6-anhydro-galactopyranose (B)

\footnotetext{
* International Union of Pure and Applied Chemistry.
}

and then heated at $90{ }^{\circ} \mathrm{C}$ for $60 \mathrm{~min}$. The liquid was drained after cooling. To remove excess alkali, seaweed samples were first rinsed with running tap water, then with $0.05 \mathrm{~N} \mathrm{H}_{2} \mathrm{SO}_{4}$ for $3 \mathrm{~min}$, and finally with distilled water. The extraction was carried out following the procedure described for the native extraction (Craigie and Leigh 1978).

\section{Physicochemical characterization}

Total carbohydrates were quantified by the phenolsulfuric acid colorimetric method (DuBois et al. 1956) using galactose as standard. 3,6-anhydrogalactose content $(3,6-$ AG) was determined by the resorcinol-acetal method of Yaphe and Arsenault (1965) modified by Craigie and Leigh (1978) using fructose as standard. To determine sulfate content, about $20 \mathrm{mg}$ of dry samples of native and alkali-treated polysaccharides were hydrolyzed with $2 \mathrm{~N} \mathrm{HCl}$ at $100{ }^{\circ} \mathrm{C}$ for $2 \mathrm{~h}$. Sulfate content was then determined by the turbidimetric method of Tabatabai modified by Craigie and Leigh (1978) una vez con etanol al 96\%; después, se secó durante 24 h a $60{ }^{\circ} \mathrm{C}$ y se pesó (Craigie y Leigh 1978).

\section{Polisacáridos solubles con tratamiento alcalino}

Muestras de $3 \mathrm{~g}$ de algas secas (por triplicado) fueron tratadas con una solución de hidróxido de potasio $(\mathrm{KOH})$ al $6 \%$ y calentadas a $90{ }^{\circ} \mathrm{C}$ durante $60 \mathrm{~min}$. Posteriormente, se enfriaron y el líquido se drenó. Para eliminar el exceso de álcali, las algas primero se lavaron con agua corriente, luego con $\mathrm{H}_{2} \mathrm{SO}_{4} 0.05 \mathrm{~N}$ durante 3 min y finalmente con agua destilada. La extracción se llevó a cabo siguiendo el procedimiento descrito para la extracción nativa (Craigie y Leigh 1978).

\section{Caracterización fisicoquímica}

Los carbohidratos totales se cuantificaron mediante el método colorimétrico de fenol-ácido sulfúrico (DuBois 
using potassium sulfate $\left(\mathrm{K}_{2} \mathrm{SO}_{4}\right)$ as standard. The molar ratio of components, galactose, 3,6-anhydrogalactose, sulfates (Gal:3,6-AG:sulfates), was calculated from the native and alkali-treated polysaccharides specially extracted for this determination. The values of the molecular weight of each component were used in the calculation, where sulfates were calculated as sodium sulfate $\left(\mathrm{SO}_{3} \mathrm{Na}\right)$. The absolute viscosity of native and alkali-treated polysaccharides was measured in millipascals per second $(\mathrm{mPa} \cdot \mathrm{s})$ in $3 \%(\mathrm{w} / \mathrm{v})$ solutions at $20{ }^{\circ} \mathrm{C}$ with a Brookfield Mod LVT viscometer with spindle No. 1 at $30 \mathrm{rpm}$.

\section{Infrared spectroscopy}

Fourier-transform infrared spectroscopy (FTIR) was applied. About $1 \mathrm{mg}$ of dry polysaccharide samples was mixed and pressed with potassium bromide $(\mathrm{KBr})$ crystals to form a translucid pellet. The spectra were then acquired in a Perkin-Elmer Spectrum 100 spectrophotometer after 10 scans at a resolution of $4 \mathrm{~cm}^{-1}$ scannings, between 400 and $4,000 \mathrm{~cm}^{-1}$ wavelengths, in transmittance mode.

\section{Statistical analysis}

All analyses were performed in triplicate. A priori tests were performed to define normality and homoscedasticity. Since the data were not normal, an analysis of variance was applied to detect significant differences among treatments $(P<0.05)$. A rank analysis (Kruskal-Wallis) and a posteriori Tukey tests were used with the non-parametric data (Zar 1999).

\section{RESULTS}

The applied alkaline treatment affected the yield and composition of the soluble polysaccharides from A. spicifera. Overall, the yields of native extractions were higher $(24.7 \%$ to $39.3 \%$ ) than those of extractions with the alkaline treatment $(9.1 \%$ to $14.9 \%)$. In the case of native extractions, the highest yield (39.4\%) was obtained in July and the lowest (26.2\%) in September (Fig. 2). When using the alkaline treatment, the highest yield (14.9\%) was obtained in April and the lowest $(9.1 \%)$ in August. Only the yield of native polysaccharides showed significant differences throughout the year $(P<0.05)$ (Fig. 2).

In addition to the changes in soluble polysaccharide yields, there was an increase in the 3,6-AG content and a decrease in the sulfate contents when applying the alkaline treatment before extraction. The 3,6-AG yields for native polysaccharides ranged from $16.48 \%$ to $20.26 \%$, and the yields for alkali-treated polysaccharides ranged from $13.80 \%$ to $25.70 \%$. Significant differences occurred throughout the year $(P<0.05)$ (Table 2). Moreover, sulfate content was higher for native polysaccharides $(8.80 \%-13.80 \%)$ than for alkali-treated polysaccharides $(4.50 \%-8.90 \%)$. Similarly, et al. 1956) utilizando galactosa como estándar. El contenido de 3,6-anhidrogalactosa (3,6-AG) se determinó por el método resorcinol-acetal de Yaphe y Arsenault (1965) modificado por Craigie y Leigh (1978) utilizando fructosa como estándar. Para determinar el contenido de sulfatos, aproximadamente $20 \mathrm{mg}$ de las muestras secas de los polisacáridos nativos y con tratamiento alcalino se hidrolizaron con $\mathrm{HCl}$ $2 \mathrm{~N}$ a $100^{\circ} \mathrm{C}$ durante $2 \mathrm{~h}$. Posteriormente, el sulfato se determinó por el método turbidimétrico de Tabatabai modificado por Craigie y Leigh (1978) utilizando como estándar sulfato de potasio $\left(\mathrm{K}_{2} \mathrm{SO}_{4}\right)$. La razón molar de componentes, galactosa, 3,6-anhidrogalactosa, sulfatos (Gal:3,6-AG:sulfatos), se calculó para los polisacáridos nativos y los polisacáridos con tratamiento alcalino especialmente extraídos para esta determinación. Se utilizaron los valores del peso molecular de cada componente para el cálculo, donde los sulfatos se calcularon como sulfato de sodio $\left(\mathrm{SO}_{3} \mathrm{Na}\right)$. La viscosidad absoluta de los polisacáridos nativos y tratados con tratamiento alcalino se midió en milipascales por segundo $(\mathrm{mPa} \cdot \mathrm{s})$ en soluciones al $3 \%(\mathrm{p} / \mathrm{v})$ a $20^{\circ} \mathrm{C}$ con un viscosímetro Brookfield Mod LVT a $30 \mathrm{rpm}$ con el rotor No. 1.

\section{Espectroscopia de infrarrojo}

Se aplicó la FTIR. Muestras de aproximadamente $1 \mathrm{mg}$ de los polisacáridos secos se mezclaron y prensaron con cristales de bromuro de potasio $(\mathrm{KBr})$ para formar una pastilla translúcida. Posteriormente, los espectros se obtuvieron en un espectrofotómetro Perkin-Elmer Spectrum 100 mediante 10 escaneos a una resolución de $4 \mathrm{~cm}^{-1}$ en el intervalo de longitudes de onda de 400 a $4,000 \mathrm{~cm}^{-1}$ en el modo de transmitancia.

\section{Análisis estadístico}

Todos los análisis se hicieron por triplicado. Se realizaron pruebas a priori para definir la normalidad y la homocedasticidad. Dado que los datos no eran normales, se aplicó un análisis de varianza para detectar diferencias significativas entre los tratamientos $(P<0.05)$. Con los datos no paramétricos se utilizó un análisis de rango (Kruskal-Wallis) y pruebas de Tukey a posteriori (Zar 1999).

\section{Resultados}

La aplicación del tratamiento alcalino afectó el rendimiento y la composición de los polisacáridos solubles de A. spicifera. En general, el rendimiento de las extracciones nativas fue mayor $(24.7 \%$ a $39.3 \%)$ que el de las extracciones con tratamiento alcalino $(9.1 \%$ a $14.9 \%)$. En las extracciones nativas, el rendimiento más alto (39.4\%) se obtuvo en julio y el más bajo (26.2\%) en septiembre (Fig. 2). Cuando se utilizó el tratamiento alcalino, el mayor rendimiento (14.9\%) se obtuvo en abril y el más bajo $(9.1 \%)$ en agosto. Sólo el rendimiento de los polisacáridos 
significant differences were observed between sampling months $(P<0.05)$ (Table 2).

The FTIR spectra of the soluble polysaccharides obtained from A. spicifera revealed the characteristic signals for sulfated galactans from red algae. A strong band was detected between 1,250 and $1,230 \mathrm{~cm}^{-1}$, with additional bands at 930 , 890,836 , and $771 \mathrm{~cm}^{-1}$. The spectrum for the alkali-treated polysaccharide showed more and better-defined signals than the corresponding spectrum for native polysaccharide (Fig. 3).

\section{Physicochemical properties}

The polysaccharide obtained from A. spicifera is nongelling and produced low-viscosity solutions, which were lower than $41 \mathrm{mPa} \cdot \mathrm{s}$ in all cases. The absolute viscosity of the native polysaccharide was significantly higher than that of the alkali-treated polysaccharide. The highest viscosity was obtained with the native process in October $(41 \mathrm{mPa} \cdot \mathrm{s})$, while the lowest $(4 \mathrm{mPa} \cdot \mathrm{s})$ was obtained with the alkaline treatment in December. An increase in the viscosity of the native polysaccharide was observed from mid summer to the beginning of fall; significant differences were observed mainly for the native polysaccharide (Fig. 4).

The molar ratio of components (Gal:3,6-AG:sulfates) showed that the A. spicifera polysaccharide is a sulfated galactan with low proportion of 3,6-AG (Table 3). The proportion of hemiester sulfate groups in the native polysaccharide was about 1 sulfate group for every 3 disaccharide units

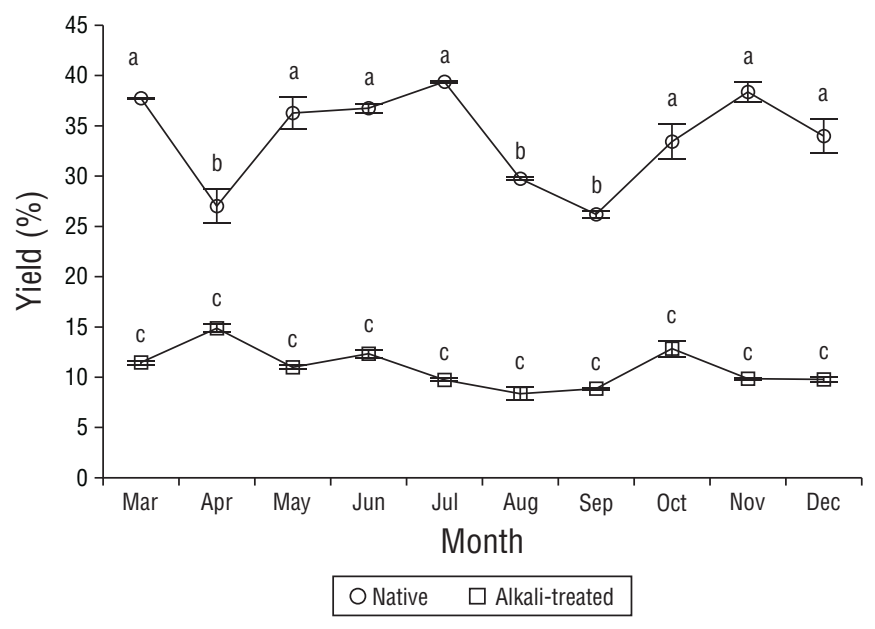

Figure 2. Monthly variation of native and alkali-treated polysaccharide yields from Acanthophora spicifera. Vertical bars are standard deviations $(n=3)$. Different letters correspond to significant differences between months.

Figura 2. Variación mensual del rendimiento del polisacárido soluble nativo y el polisacárido soluble con tratamiento alcalino de Acanthophora spicifera. Las barras verticales indican la desviación estándar $(n=3)$. Las letras diferentes corresponden a diferencias significativas entre los meses. nativos mostró diferencias significativas a lo largo del año $(P<0.05)$ (Fig. 2).

Mediante la aplicación del tratamiento alcalino antes de la extracción, además de los cambios en el rendimiento de polisacáridos solubles, en general, hubo un aumento en el contenido de 3,6-AG y una disminución en el contenido de sulfatos. El rendimiento de 3,6-AG para los polisacáridos nativos varió de $16.48 \%$ a $20.26 \%$, y el rendimiento para los polisacáridos con tratamiento alcalino varió de $13.80 \%$ a $25.70 \%$. Se observaron diferencias significativas $(P<0.05)$ a lo largo del año (Tabla 2). Además, el contenido de sulfatos fue mayor para los polisacáridos nativos $(8.80 \%-13.70 \%)$ que para los polisacáridos con tratamiento alcalino $(4.50 \%-$ $8.90 \%)$. De igual manera, se observan diferencias significativas entre los meses de muestreo $(P<0.05)$ (Tabla 2$)$.

Los espectros FTIR de los polisacáridos solubles obtenidos de A. spicifera revelaron las señales características para los galactanos sulfatados de algas rojas. Se detectó una banda fuerte en $1,250-1,230 \mathrm{~cm}^{-1} \mathrm{y}$ bandas adicionales en $930,890,836$ y $771 \mathrm{~cm}^{-1}$. El espectro del polisacárido con tratamiento alcalino mostró más señales y mejor definidas que el espectro correspondiente al polisacárido nativo (Fig. 3).

\section{Propiedades fisicoquímicas}

Los polisacáridos obtenidos de A. spicifera no fueron gelificantes y produjeron soluciones de baja viscosidad, que en todos los casos fueron inferiores a $41 \mathrm{mPa} \cdot \mathrm{s}$. La viscosidad absoluta del polisacárido nativo fue significativamente mayor que el polisacárido tratado con álcalis. La viscosidad más alta se obtuvo con el proceso nativo en octubre (41 $\mathrm{mPa} \cdot \mathrm{s})$, mientras que la más baja (4 $\mathrm{mPa} \cdot \mathrm{s})$ se obtuvo en diciembre con el polisacárido con tratamiento alcalino. Se observó un incremento en la viscosidad del polisacárido nativo desde mediados de verano hasta principios de otoño; se observaron diferencias significativas principalmente para el polisacárido nativo (Fig. 4).

La razón molar de componentes (Gal:3,6-AG:sulfatos) demostró que los polisacáridos de $A$. spicifera son galactanos sulfatados con una proporción baja de 3,6-AG (Tabla 3). La proporción de grupos hemiéster sulfato en el polisacárido nativo fue de aproximadamente un grupo sulfato por cada 3 unidades disacáridas (A-B), mientras que con el tratamiento alcalino, disminuyó a un grupo sulfato por casi cada 4 unidades disacáridas (Tabla 3).

\section{Discusión}

Las algas marinas pertenecientes a la familia Rhodophyceae son fuente importante de polisacáridos sulfatados, ya sea tipo agar o carragenano (Painter 1983, Craigie 1990, Lobban y Harrison 1994). Para aislar y caracterizar los polisacáridos solubles de algas rojas, generalmente además de obtener el polisacárido nativo, es necesario aplicar un tratamiento 
Table 2. Monthly variation of the 3,6-anhydrogalactose (3,6-AG) and sulfate contents in native and alkali-treated polysaccharides from Acanthophora spicifera. Data are presented as the mean of triplicate assays $(n=3)$. Different letters indicate significant differences between months.

Tabla 2. Variación mensual del contenido de 3,6-anhidrogalactosa (3,6-AG) y de sulfato en los polisacáridos nativos y los polisacáridos tratados con álcali de Acanthophora spicifera. Los datos se presentan como la media de ensayos por triplicado $(n=3)$. Las letras diferentes indican diferencias significativas entre meses.

\begin{tabular}{lcccc}
\hline & \multicolumn{2}{c}{$\begin{array}{c}3,6 \mathrm{AG} \\
(\%)\end{array}$} & Native & $\begin{array}{c}\text { Sulfate } \\
(\%)\end{array}$ \\
\cline { 2 - 5 } Month & Native & Alkali-treated & $13.80 \pm 0.15^{\mathrm{e}}$ & $7.00 \pm 0.12^{\mathrm{d}}$ \\
\hline March & $19.70 \pm 0.37^{\mathrm{e}}$ & $19.40 \pm 0.14^{\mathrm{b}}$ & $11.50 \pm 0.18^{\mathrm{d}}$ & $6.50 \pm 0.05^{\mathrm{c}}$ \\
April & $19.40 \pm 0.13^{\mathrm{e}}$ & $19.50 \pm 0.20^{\mathrm{b}}$ & $10.50 \pm 0.07^{\mathrm{c}}$ & $4.50 \pm 0.07^{\mathrm{a}}$ \\
May & $19.60 \pm 0.11^{\mathrm{e}}$ & $13.80 \pm 0.02^{\mathrm{a}}$ & $8.80 \pm 0.05^{\mathrm{a}}$ & $8.90 \pm 0.10^{\mathrm{e}}$ \\
June & $16.48 \pm 0.13^{\mathrm{a}}$ & $25.70 \pm 0.92^{\mathrm{f}}$ & $13.70 \pm 0.07^{\mathrm{e}}$ & $6.80 \pm 0.14^{\mathrm{c}}$ \\
July & $20.26 \pm 0.01^{\mathrm{d}}$ & $22.29 \pm 0.10^{\mathrm{e}}$ & $10.30 \pm 0.03^{\mathrm{c}}$ & $5.40 \pm 0.07^{\mathrm{b}}$ \\
August & $18.19 \pm 0.09^{\mathrm{c}}$ & $20.64 \pm 0.07^{\mathrm{c}}$ & $10.20 \pm 0.28^{\mathrm{c}}$ & $6.80 \pm 0.01^{\mathrm{c}}$ \\
September & $17.17 \pm 0.32^{\mathrm{b}}$ & $19.52 \pm 0.40^{\mathrm{b}}$ & $11.10 \pm 0.13^{\mathrm{d}}$ & $7.80 \pm 0.12^{\mathrm{d}}$ \\
October & $18.23 \pm 0.13^{\mathrm{c}}$ & $21.03 \pm 0.09^{\mathrm{d}}$ & $10.90 \pm 0.17^{\mathrm{c}}$ & $6.70 \pm 0.05^{\mathrm{c}}$ \\
November & $19.96 \pm 0.12^{\mathrm{e}}$ & $20.13 \pm 0.53^{\mathrm{c}}$ & $9.92 \pm 0.06^{\mathrm{b}}$ & $7.60 \pm 0.18^{\mathrm{d}}$ \\
December & $17.20 \pm 0.09^{\mathrm{b}}$ & $19.71 \pm 0.47^{\mathrm{b}}$ & & \\
\hline
\end{tabular}

(A-B), while with the alkaline treatment, it decreased to 1 sulfate group for almost every 4 disaccharide units (Table 3 ).

\section{Discussion}

Seaweeds belonging to the Rhodophyceae family are important sources of sulfated polysaccharides, either the agar or the carrageenan types (Painter 1983, Craigie 1990, Lobban and Harrison 1994). To isolate and characterize soluble polysaccharides from red seaweeds, usually in addition to obtaining the native polysaccharide, it is also necessary to apply an alkaline treatment, as it produces more chemically homogeneous molecules and, in some cases, enhances gelforming properties (Hoffmann et al. 1995, Usov 2011).

In this study native and alkali-treated soluble polysaccharides from the red seaweed A. spicifera from La Paz Bay, Baja California Sur, Mexico, were extracted and characterized. As expected, when using the alkaline treatment on the raw material, given the high temperature and high alkali concentration, the 4-linked $\alpha$-galactopyranose 6-sulfate (B unit) (Table $1 \mathrm{~b}$ ) transformed into 3,6-anhydro $\alpha$-galactopyranose (Table 1c). The alkaline treatment modifies the composition and properties of polysaccharides in red seaweeds (Kloareg and Quatrano 1988, Craigie 1990, Usov 2011); however, it also entails some degradation and loss of the polysaccharide (Stanley 1987, Myslabodski 1990). Therefore, in this study, the native extraction yields $(24.7 \%$ to $39.3 \%)$ were higher than the extractions with the alkaline treatment (9.1\% to $14.9 \%$ ) (Fig. 2); by contrast, there was an increase in the alcalino, ya que produce moléculas químicamente más homogéneas y, en algunos casos, mejora sus propiedades de gelificación (Hoffmann et al. 1995, Usov 2011).

En este estudio se extrajeron y caracterizaron los polisacáridos solubles nativos y con tratamiento alcalino del alga roja A. spicifera de la bahía de La Paz, Baja California Sur, México. Como era de esperar, al aplicar el tratamiento alcalino a la materia prima, debido a la alta temperatura y alta concentración de álcalis, la molécula unida en $4 \alpha$-galactopiranosa 6-sulfato (unidad B) (Tabla 1b) se transformó en 3,6-anhidro $\alpha$-galactopiranosa (Tabla 1c). El tratamiento alcalino modifica la composición y las propiedades de los polisacáridos en las algas rojas (Kloareg y Quatrano 1988, Craigie 1990, Usov 2011); sin embargo, también implica cierta degradación y pérdida del polisacárido (Stanley 1987, Myslabodski, 1990). Por lo tanto, en este estudio, los rendimientos de las extracciones nativas $(24.7 \%$ a $39.3 \%)$ fueron superiores a los rendimientos de las extracciones con tratamiento alcalino (9.1\% a $14.9 \%$ ) (Fig. 2); en cambio, hubo un aumento en el contenido de 3,6-AG y una disminución concurrente en el contenido de sulfatos (Tabla 2). La misma tendencia de rendimientos bajos e incremento en el contenido de la 3,6-AG se obtuvo para algunas especies productoras de agar tratadas con álcalis (Freile-Pelegrín y Robledo 1997, Arvizu-Higuera et al. 2007, Orduña-Rojas et al. 2008) y para especies de algas productoras de carragenano (Craigie 1990, Freile-Pelegrín et al. 2006).

Con base en los espectros de FTIR, algunos autores han clasificado los polisacáridos de A. spicifera como 
3,6-AG content and a concurrent decrease in sulfate content (Table 2). The same trend, lower yields and increased 3,6-AG content, was observed for some alkali-treated agar-producing species (Freile-Pelegrín and Robledo 1997, Arvizu-Higuera et al. 2007, Orduña-Rojas et al. 2008) and for carrageenanproducing seaweeds (Craigie 1990, Freile-Pelegrín et al. 2006).

Using FTIR spectra, some authors have classified the polysaccharides from A. spicifera as carrageenans, particularly of the lambda $(\lambda)$ type (Parekh et al. 1989, Cajipe 1990, Pickering and Mario 1999, Gomaa and Elshoubaky 2016). $\lambda$-Carrageenan is a highly sulfated galactan that yields high viscous solutions but has no gelling properties; it has been chemically characterized (data not shown) and its composition has high contents of sulfate groups $(35 \%$ to $40 \%$ ) and only traces of 3,6-AG. In this study, we found that $A$. spicifera polysaccharides also have no gelling properties, and unlike carrageenans they produce solutions with very low viscosity, even after the alkaline treatment (Fig. 4). Compared to $\lambda$-carrageenan, the chemical composition of the A. spicifera polysaccharide (native) has lower sulfate content ( $8.8 \%$ to $13.8 \%$ ) and higher $3,6-\mathrm{AG}$ content $(17.0 \%$ to $20.0 \%$ for native polysaccharides) (Table 2). Futhermore, the molar ratio (G:3,6-AG:sulfates) for $\lambda$-carrageenan is 1.00:0.13:1.10 (experimental data, not shown), whereas for the A. spicifera polysaccharides it is 1.00:0.30:0.23 for the native polysaccharide and 1.00:0.30:0.17 for the alkali-treated polysaccharide

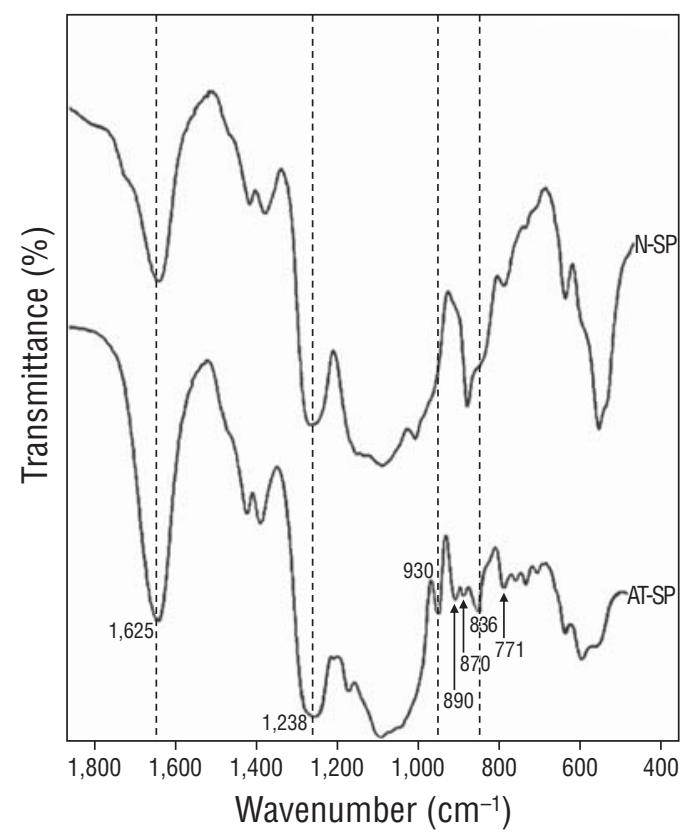

Figure 3. Fourier-transform infrared spectra of native (N-SP) and alkali-treated (AT-SP) soluble polysaccharides from Acanthophora spicifera.

Figura 3. Espectros de infrarrojo con transformada de Fourier del polisacárido soluble nativo (N-SP) y el polisacárido soluble con tratamiento alcalino (AT-PS) de Acanthophora spicifera. carragenanos, particularmente del tipo lambda $(\lambda)$ (Parekh et al. 1989, Cajipe 1990, Pickering y Mario 1999, Gomaa y Elshoubaky 2016). El $\lambda$-carragenano es un galactano altamente sulfatado que produce soluciones de alta viscosidad, pero carece de propiedades gelificantes; se ha caracterizado químicamente (datos no mostrados) y su composición tiene un alto contenido de grupos sulfato $(35 \%$ a $40 \%)$ y sólo trazas de 3,6-AG. En este estudio, encontramos que los polisacáridos de A. spicifera tampoco tienen propiedades gelificantes, pero, a diferencia del $\lambda$-carragenano, producen soluciones de muy baja viscosidad, incluso después del tratamiento alcalino (Fig. 4). En comparación con el $\lambda$-carragenano, la composición química del polisacárido de A. spicifera (nativo) tiene menor contenido de sulfatos $(8.8 \%$ a $13.8 \%)$ y un contenido mayor de $3,6-\mathrm{AG}$ $(17.0 \%$ a $20.0 \%$ en los polisacáridos nativos) (Tabla 2). De la misma manera, la razón molar (G:3,6AG:sulfatos) para $\lambda$-carragenano es 1.00:0.13:1.10 (datos experimentales, no mostrados), mientras que para los polisacáridos de A. spicifera, es 1.00:0.30:0.23 para el polisacárido nativo y 1.00:0.30:0.17 para el polisacárido con tratamiento alcalino (Tabla 3); sin embargo, la composición del polisacárido de A. spicifera también difiere del agar verdadero, el cual posee un contenido de 3,6-AG más alto y un menor contenido de sulfato, con una relación molar ideal de 1.00:1.00:0.00 (Armisen y Galatas 1987, Craigie 1990).

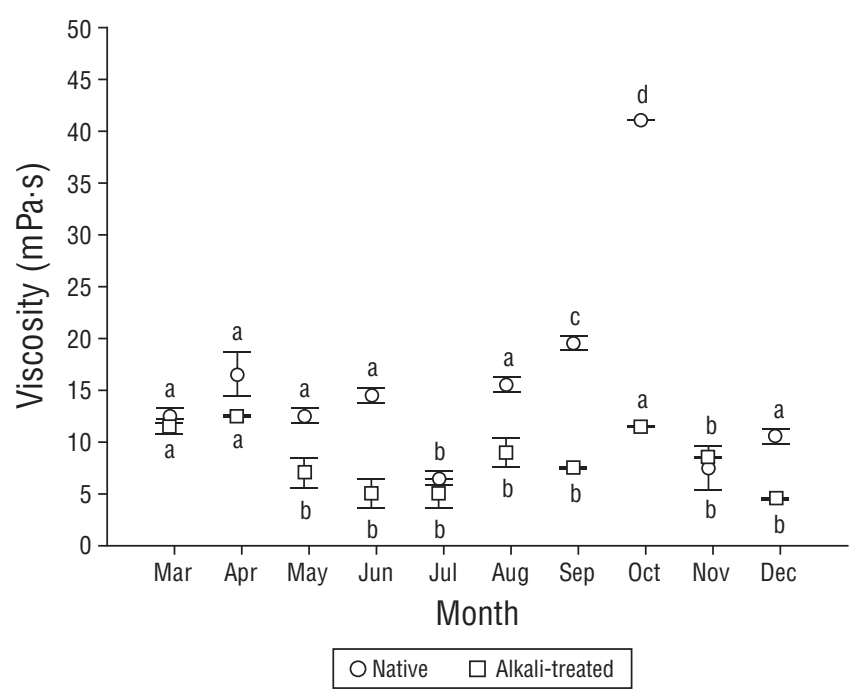

Figure 4. Absolute viscosity of native and alkali-treated polysaccharides measured with a Brookfield viscometer with spindle 1 at $30 \mathrm{rpm}$. Vertical bars are standard deviations $(n=3)$. Different letters indicate significant differences between months.

Figura 4. Viscosidad absoluta $(\mathrm{mPa} \cdot \mathrm{S})$ del polisacárido nativo y el polisacárido con tratamiento alcalino medida con un viscosímetro Brookfield con rotor No. 1 a $30 \mathrm{rpm}$. Las barras verticales indican la desviación estándar $(n=3)$. Las letras diferentes indican diferencias significativas entre los meses. 
Table 3. Composition, molar proportion (galactose [Gal], 3,6-anhydrogalactose [3,6-AG], sulfates), and molar ratio of native and alkali-treated polysaccharides from Acanthophora spicifera.

Tabla 3. Composición, proporción molar (galactosa[Gal], 3,6-anhidrogalactosa [3,6-AG], sulfatos) y razón molar de los polisacáridos nativos y los polisacáridos tratados con álcali de Acanthophora spicifera.

\begin{tabular}{|c|c|c|c|c|c|c|c|c|c|}
\hline \multirow[b]{2}{*}{ Treatment } & \multicolumn{3}{|c|}{ Content $(\%)$} & \multicolumn{3}{|c|}{ Molar proportion } & \multicolumn{3}{|c|}{ Molar ratio } \\
\hline & $\mathrm{Gal}$ & 3,6-AG & Sulfate & Gal & 3,6-AG & Sulfate & Gal & 3,6-AG & Sulfate \\
\hline Native & 70.74 & 18.96 & 10.30 & 0.44 & 0.13 & 0.10 & 1.00 & 0.30 & 0.23 \\
\hline Alkali-treated & 72.47 & 19.62 & 7.91 & 0.45 & 0.14 & 0.08 & 1.00 & 0.30 & 0.17 \\
\hline
\end{tabular}

(Table 3); however, the A. spicifera polysaccharide composition also differs from true agar, which has higher 3,6-AG content and lower sulfate content, with an ideal molar ratio of 1.00:1.00:0.00 (Armisen and Galatas 1987, Craigie 1990).

On the other hand, studies on A. spicifera polysaccharides have shown that the soluble polysaccharides in this species belong to the agaran family (Gonçalvez et al. 2002, Duarte et al. 2004). They are known to be highly sulfated on $\mathrm{C}$-2, with pyruvic acid linked as a cyclic ketal bridge at 4,6-O-(1'-carboxyethylidene groups) in the 1-3linked A unit (Duarte et al. 2004). This is in agreement with the fact that the polysaccharides found in other algae belonging to the order Ceramiales biosynthesize sulfated agarans (Painter 1983, Craigie 1990, Usov 2011).

In this study, the FTIR spectra of the A. spicifera polysaccharides showed that these are highly sulfated polysaccharides with pyruvic acid, as shown by the presence of a strong signal between 1,240 and 1,260 $\mathrm{cm}^{-1}$ (asymmetric stretching of $\mathrm{O}=\mathrm{S}=\mathrm{O}$ ) (Stancioff and Stanley 1969) and a double signal at 1,637 and $1,417 \mathrm{~cm}^{-1}$ for the pyruvic acid carboxylic group (Prado-Fernández et al. 2003). The spectra of the alkali-treated polysaccharides showed better-defined signals between 1,000 and $700 \mathrm{~cm}^{-1}$ because of the loss of the labile sulfate in C-6 of the B unit and the concurrent 3,6-AG formation. This revealed the signal at $930 \mathrm{~cm}^{-1}$ because of 3,6-AG (Rochas et al. 1986) and a signal at $890 \mathrm{~cm}^{-1}$ for desulfated galactose (Greer and Yaphe 1984). Both signals are absent in $\lambda$-carrageenan but are characteristic of agars (Armisen and Galatas 1987, Barros et al. 2013, Gómez-Ordóñez and Rupérez 2011). There was also a strong signal at $830 \mathrm{~cm}^{-1}$, which corresponded to the equatorial sulfate in galactose 2-sulfate (Rochas et al. 1986), and signals at 790 and $717 \mathrm{~cm}^{-1}$, which are characteristic of agar (Matsuhiro and Miller 2002) (Fig. 3). Our results suggest that the soluble polysaccharides in A. spicifera belong to the agaran family; however, given their composition and properties, they must be considered deviants of the true agar (agaroids) (Craigie 1990). On the other hand, despite the deficient viscosity and gelling properties of some polyssacharides, it should be noted that sulfated galactans in red seaweeds usually show potent antiviral activity (Carlucci et al. 1997, Damonte et al. 2004), where the inhibitory effect is attributed to their negatively charged sulfated polysaccharides because of
Por otro lado, estudios sobre los polisacáridos de A. spicifera demostraron que los polisacáridos solubles de esta especie pertenecen a la familia de agaranos (Gonçalvez et al. 2002, Duarte et al. 2004). Se sabe que están altamente sulfatados en C-2, con el ácido pirúvico unido como un cetal cíclico en 4,6-O-(grupos de 1'-carboxietiliden) en la unidad A enlazada en 1-3 (Duarte et al. 2004). Esto concuerda con el hecho de que los polisacáridos encontrados en otras algas pertenecientes al orden Ceramiales biosintetizan agaranos sulfatados (Painter 1983, Craigie 1990, Usov 2011).

En este estudio los espectros FTIR de los polisacáridos de A. spicifera mostraron que se trata de polisacáridos altamente sulfatados y con ácido pirúvico, como lo demuestra la presencia de una señal fuerte en 1,240-1,260 $\mathrm{cm}^{-1}$ (estiramiento asimétrico de $\mathrm{O}=\mathrm{S}=\mathrm{O}$ ) (Stancioff y Stanley 1969) y una doble señal en 1,637 y $1,417 \mathrm{~cm}^{-1}$ para el grupo carboxilo del ácido pirúvico (Prado-Fernández et al. 2003). Los espectros de los polisacáridos con tratamiento alcalino mostraron señales mejor definidas en el intervalo de 1,000 a $700 \mathrm{~cm}^{-1}$ debido a la pérdida del sulfato lábil en C-6 de la unidad B y la consecuente formación de 3,6-AG. Esto hizo visible la señal en $930 \mathrm{~cm}^{-1}$ debido a la 3,6-AG (Rochas et al. 1986) y la señal en $890 \mathrm{~cm}^{-1}$ para la galactosa desulfatada (Greer y Yaphe 1984). Ambas señales están ausentes en el $\lambda$-carragenanos, pero son características del agar (Armisen y Galatas 1987, Barros et al. 2013, Gómez-Ordóñez y Rupérez 2011). También hubo una señal fuerte en $830 \mathrm{~cm}^{-1}$, correspondiente al sulfato ecuatorial de galactosa-2-sulfato (Rochas et al. 1986), y se presentaron señales en 790 y $717 \mathrm{~cm}^{-1}$, que son características del agar (Matsuhiro y Miller 2002) (Fig. 3). Nuestros resultados sugieren que los polisacáridos solubles de A. spicifera pertenecen a la familia de agaranos; sin embargo, debido a su composición y sus propiedades, deben ser considerados como variantes del verdadero agar (agaroideos) (Craigie 1990). Por otro lado, a pesar de la deficiencia en viscosidad y propiedades gelificantes de algunos polisacáridos de algas rojas, cabe destacar que los galactanos sulfatados de las algas rojas suelen presentar una potente actividad antiviral (Carlucci et al. 1997, Damonte et al. 2004), donde el efecto inhibitorio se atribuye a sus polisacáridos sulfatados cargados negativamente, debido, probablemente, a la similitud conformacional entre las unidades disacáridas repetitivas de los galactanos sulfatados 
the possible conformational similarity between disaccharide repeating units of sulfated galactans and heparan sulfate, which serves as a negatively charged cell-surface target for most viruses (Chen et al. 1997, Duarte et al. 2004, Usov 2011). Considering mainly the composition and properties of the polysaccharides found in this study, A. spicifera cannot be considered a good source of agar; however, it could alternatively be used for its possible antiviral activity (Duarte et al. 2004, Bouhlal et al. 2011, Gomaa and Elshoubaky 2016) or its possible anti-inflammatory properties, as described for Acanthophora muscoides (Quinderé et al. 2013).

\section{ACKNOWLEDGMENTS}

We thank the institutions that provided support for this research (CICIMAR-IPN, CRIAP/Ensenada-INAPESCA). Thanks are also due to the National Council for Science and Technology (Mexico), IPN Comisión de Operación y Fomento de Actividades Académicas (COFAA), and Beca De Estímulo Institucional de Formación de Investigadores for granting VCGS a scholarship. GHC thanks IPN for the productivity grants provided by COFAA and Estímulo al Desempeño de los Investigadores and the economic stimulus granted by the Mexican National System of Researchers (Sistema Nacional de Investigadores). The Faculty of Marine Sciences at UABC facilitated use of the FTIR spectrometer. We thank Blanca Esther García Espinosa for her assistance and the anonymous reviewers for their valuable suggestions.

\section{REFERENCES}

Armisen R, Galatas F. 1987. Production, properties, and uses of Agar. In: McHugh DJ (ed.), Production and utilization of products from commercial seaweeds. FAO Fisheries Technical Paper. No. 288: Food and Agriculture Organization of the United Nations. p. 1-57.

Arvizu-Higuera DL, Rodríguez-Montesinos YE, Murillo-Álvarez JI, Muñoz-Ochoa M, Hernández-Carmona G. 2007. Effect of alkali treatment time and extraction time on agar from Gracilaria vermiculophylla. In: Borowitzka MA, Critchley AT, Kraan S, Peters A, Sjøtun K, Notoya M (eds.), Nineteenth International Seaweed Symposium. Vol. 2, Developments in Applied Phycology. Dordrecht (Netherlands): Springer. p. 65-69.

https://doi.org/10.1007/978-1-4020-9619-8_9

Barros FCN, da Silva DC, Sombra VG, Maciel JS, Feitosa JPA, Freitas ALP, de Paula RCM. 2013. Structural characterization of polysaccharide obtained from red seaweed Gracilaria caudata (J Agardh). Carbohydrate Polymers. 92(1):598-603. https://doi.org/10.1016/j.carbpol.2012.09.009

Børgesen F. 1910. Some new or little known West Indian Florideae. II. Botanisk Tidsskrift. 30:177-207, 20 figs.

Bouhlal R, Haslin C, Chermann J-C, Colliec-Jouault S, Sinquin C, Simon G, Cerantola S, Riadi H, Bourgougnon N. 2011. Antiviral activities of sulfated polysaccharides isolated from Sphaerococcus coronopifolius (Rhodophyta, Gigartinales) and y el heparán sulfato, el cual sirve como punto de unión en la superficie celular cargada negativamente para la mayoría de los virus (Chen et al. 1997, Duarte et al. 2004, Usov 2011). Entonces, con base en principalmente la composición y las propiedades de los polisacáridos encontrados en este estudio, A. spicifera no se considera como una buena fuente de agar; sin embargo, podría ser utilizada, alternativamente, por sus posibles propiedades antivirales (Duarte et al. 2004, Bouhlal et al. 2011, Gomaa y Elshoubaky 2016) o sus posibles propiedades antiinflamatorias, como se ha descrito para Acanthophora muscoides (Quinderé et al. 2013).

\section{Agradecimientos}

Agradecemos a las instituciones que brindaron su apoyo para llevar a cabo esta investigación (CICIMAR-IPN, CRIAP/ Ensenada-INAPESCA). También agradecemos al Consejo Nacional de Ciencia y Tecnología (México), la Comisión de Operación y Fomento de Actividades Académicas (COFAA) del IPN y la Beca De Estímulo Institucional de Formación de Investigadores la beca otorgada a VCGS. GHC agradece al IPN las becas de productividad otorgadas por la COFAA y el Estímulo al Desempeño de los Investigadores, así como el estímulo económico otorgado por el Sistema Nacional de Investigadores (México). La Facultad de Ciencias Marinas de UABC facilitó el espectrofotómetro. Agradecemos a Blanca Esther García-Espinosa por su ayuda y a los revisores anónimos por sus valiosas sugerencias.

Boergeseniella thuyoides (Rhodophyta, Ceramiales). Mar Drugs. 9(7):1187-1209.

https://doi.org/10.3390/md9071187

Cajipe GJB. 1990. Utilization of seaweed resources. In: Dogma IJ Jr, Trono GC Jr, Tabbada RA (eds.), Culture and use of algae in Southeast Asia: Proceedings of the Symposium on Culture and Utilization of Algae in Southeast Asia; 8-11 December 1981; Tigbauan, Iloilo, Philippines. Philippines: Aquaculture Department, Southeast Asian Fisheries Development Center. p. 77-79.

Carlucci MJ, Scolaro LA, Errea MI, Matulewicz MC, Damonte EB. 1997. Antiviral activity of natural sulphated galactans on herpes virus multiplication in cell culture. Planta Med. 63(5):429-432. https://doi.org/10.1055/s-2006-957727

Chen Y, Maguire T, Hileman RE, Fromm JR, Esko JD, Linhardt RJ, Marks RM. 1997. Dengue virus infectivity depends on envelope protein binding to target cell heparan sulfate. Nat Med. 3(8):866-871. https://doi.org/10.1038/nm0897-866

Craigie JS. 1990. Cell walls. In: Cole KM, Sheath RG (eds.), Biology of the Red Algae. Cambridge (UK): Cambridge University Press. p. 221-257.

Craigie JS, Leigh C. 1978. Carrageenans and agars. In: Hellebust JA, Craigie JS (eds.), Handbook of phycological methods: physiological and biochemical methods. New York: Cambridge University Press. p. 110-131. 
Damonte EB, Matulewicz MC, Cerezo AS. 2004. Sulfated seaweed polysaccharides as antiviral agents. Curr Med Chem. 11(18):2399-2419. https://doi.org/10.2174/0929867043364504

Duarte MER, Cauduro JP, Noseda DG, Noseda MD, Gonçalves AG, Pujol CA, Damonte EB, Cerezo AS. 2004. The structure of the agaran sulfate from Acanthophora spicifera (Rhodomelaceae, Ceramiales) and its antiviral activity. Relation between structure and antiviral activity in agarans. Carbohydr Res. 339(2):335-347.

https://doi.org/10.1016/j.carres.2003.09.028

DuBois M, Gilles KA, Hamilton JK, Rebers PA, Smith F. 1956. Colorimetric method for determination of sugars and related substances. Anal Chem. 28(3):350-356. https://doi.org/10.1021/ac60111a017

Freile-Pelegrín Y, Robledo D. 1997. Influence of alkali treatment on agar from Gracilaria cornea from Yucatán, México. J App Phycol. 9(6):533-539. https://doi.org/10.1023/A:1007989931915

Freile-Pelegrín Y, Robledo D, Azamar JA. 2006. Carrageenan of Eucheuma isiforme (Solieriaceae, Rhodophyta) from Yucatán, Mexico. I. Effect of extraction conditions. Bot Mar. 49: 65-71. https://doi.org/10.1515/BOT.2006.008

Gomaa HHA, Elshoubaky GA. 2016. Antiviral activity of sulfated polysaccharides carrageenan from some marine seaweeds. International Journal of Current Pharmaceutical Review and Research. 7(1):34-42.

Gómez-Ordóñez E, Rupérez P. 2011. FTIR-ATR spectroscopy as a tool for polysaccharide identification in edible brown and red seaweed. Food Hydro. 25(6):1514-1520.

https://doi.org/10.1016/j.foodhyd.2011.02.009

Gonçalvez AG, Ducatti DRB, Duarte MER, Noseda MD. 2002. Sulfated and pyruvylated disaccharide alditols obtained from a red seaweed galactan: ESIMS and NMR approaches. Carbohydr Res. 337(24):2443-2453.

https://doi.org/10.1016/S0008-6215(02)00318-X

Greer CW, Yaphe W. 1984. Characterization of hybrid (BethaKappa-Gamma) carrageenan from Eucheuma gelatinae J. Agardh (Rhodophyta, Solieriaceae) using carrageenases, infrared and ${ }^{13} \mathrm{C}$-nuclear magnetic resonance spectroscopy. Bot Mar. 27(10):473-478.

https://doi.org/10.1515/botm.1984.27.10.473

Hoffmann RA, Gidley MJ, Cooke D, Frith WJ. 1995. Effect of isolation procedures on the molecular composition and physical properties of Eucheuma cottonii carrageenan. Food Hydrocolloids. 9(4):281-289. https://doi.org/10.1016/s0268-005x(09)80259-2

Kloareg B, Quatrano RS. 1988. Structure of the cell walls of marine algae and ecophysiological functions of the matrix polysaccharides. Oceanogr Mar Biol Annu Rev. 26:259-315.

Lobban CS, Harrison PJ. 1994. Seaweed ecology and physiology. Cambridge: Cambridge University Press. 66 p. https://doi.org/10.1017/CBO9780511626210

Matsuhiro B, Miller LG. 2002. Soluble polysaccharides from Rhodymenia: Characterization by FT-IR spectroscopy. Bol Soc Chil Quím. 47(3):265-271. https://dx.doi.org/10.4067/S0366-16442002000300010

Miller IJ. 1997. The chemotaxonomic significance of the watersoluble red algal polysaccharides. Recent Res Dev Phytochem. 1:531-565.

Myslabodski DE. 1990. Red-algae galactans: Isolation and recovery procedures-Effects on the structure and rheology [dissertation]. [Trondheim (Norway)]: Norwegian Institute of Technology.
Orduña-Rojas J, Suárez-Castro R, López-Álvarez ES, RíosmenaRodríguez R, Pacheco-Ruiz I, Zertuche-González JA, MelingLópez AE. 2008. Influence of alkali treatment on agar from Gracilariopsis longissima and Gracilaria vermiculophylla from the Gulf of California, Mexico = Influencia del tratamiento alcalino en el agar de Gracilariopsis longissima y Gracilaria vermiculophylla del Golfo de California México. Cienc Mar. 34(4):503-511. https://doi.org/10.7773/cm.v34i4.1383

Painter TJ. 1983. Algal polysaccharides. In: Aspinall GO (ed.), The polysaccharides. New York: Academic Press. p. 195-285.

Parekh RG, Doshi YA, Chauhan VD. 1989. Polysaccharides from marine red algae Acanthophora spicifera, Grateloupia indica and Halymenia porphyroides. Indian J Mar Sci. 18(2):139-140.

Pedroche FF, Sentíes AG. 2003. Ficología marina mexicana. Diversidad y Problemática actual. Hidrobiológica. 13(1):23-32.

Pickering T, Mario S. 1999. Survey of commercial seaweeds in South-east Viti Levu (Fiji Islands): A preliminary study on the farming potential of seaweed species present in Fiji. Suva (Fiji): Food and Agriculture Organisation of the United Nations, Fisheries and Aquaculture Department; [accessed 2000 September 1]. http://www.fao.org/docrep/005/AC880E/AC880E00.htm\#TOC.

Prado-Fernández J, Rodríguez-Vázquez JA, Tojo E, Andrade JM. 2003. Quantitation of $\kappa$-, $1-$ and $\lambda$-carrageenans by midinfrared spectroscopy and PLS regression. Anal Chim Acta. 480(1):23-37. https://doi.org/10.1016/S0003-2670(02)01592-1

Quinderé ALG, Fontes BR, Vanderlei E de SO, de Queiroz INL, Rodrigues JAG, de Araújo IWF, Jorge RJB, de Menezes DB, e Silva AAR, Chaves HV, et al. 2013. Peripheral antinociception and anti-edematogenic effect of a sulfated polysaccharide from Acanthophora muscoides. Pharmacol Rep. 65(3):600-613. https://doi.org/10.1016/s1734-1140(13)71037-5

Riosmena-Rodríguez R, Ruiz G, Hernández-Kantún J. 2009. Invasión de algas exóticas en el Golfo de California: amenaza para el ambiente y la economía regionales. La Paz (Mexico): Análisis Periodísticos BCS. p. 25-26.

Robledo D. 1998. Seaweed resources of Mexico. In: Critchley AT, Ohno M (eds.), Seaweed resources of the world. Tokyo: Japanese International Cooperation Agency. p. 331-342.

Rochas C, Lahaye M, Yaphe W. 1986. Sulfate content of carrageenan and agar determined by infrared spectroscopy. Bot Mar. 29(4):335-340. https://doi.org/10.1515/botm.1986.29.4.335

Russell DJ. 1992. The ecological invasion of Hawaiian reefs by two marine red algae, Acanthophora spicifera (Vahl) Boerg. and Hypnea musciformis (Wulfen) J. Ag., and their association with two native species, Laurencia nidifica and Hypnea cervicornis J.Ag. ICES Mar Sci Symp. 194:110-125.

Seixas C, Barragán V, Escobar C, Fuentes J. 2007. Contenido y calidad del agar extraído de muestras de Acanthophora spicifera (Vahl) Borgesen (Rhodophyta) provenientes del caribe de Panamá. Tecnociencia. 9(1):7-13.

Stancioff DJ, Stanley NF. 1969. Infrared and chemical studies on algal polysaccharides. Proc Int Seaweed Symp. 6:595-609.

Stanley N. 1987. Production, properties and uses of carrageenan. In: McHugh DJ (ed.), Production and Utilization of Products from Commercial Seaweeds. FAO Fisheries Technical Paper. Rome (Italy): Food and Agriculture organization of the United Nations. p. 116-146. Paper No. 288. 
Tsuda RT, Coles SL, Guinther EB, Finlay O, Andrew R, Harris FL. 2008. Acanthophora spicifera (Rhodophyta: Rhodomelaceae) in the Marshall Islands. Micronesica. 40(1/2):245-252.

Usov AI. 2011. Polysaccharides of the red algae. Adv Carbohydr Chem Biochem. 65:115-217. https://doi.org/10.1016/B978-0-12-385520-6.00004-2

Usov AI, Zelinsky ND. 2013. Chemical structures of algal polysaccharides. In: Domínguez H (ed.), Functional Ingredients from Algae for Foods and Nutraceuticals. Cambridge (UK): Elsevier Science. p. 45-49.
Williams SL, Smith JE. 2007. A global review of the distribution, taxonomy, and impacts of introduced seaweeds. Annu Rev Ecol Evol Syst. 38(1):327-359.

https://doi.org/10.1146/annurev.ecolsys.38.091206.095543

Yaphe W, Arsenault GP. 1965. Improved resorcinol reagent for the determination of fructose and 3,6-anhydrogalactose in polysaccharides. Analyt Biochem. 13(1):143-148. https://doi.org/10.1016/0003-2697(65)90128-4

Zar JH. 1999. Biostatistical analysis. New Jersey (USA): PrenticeHall. 663 p.

Received January 2020, accepted May 2020. 